\title{
Unstimulated Salivary Flow Rate Corresponds with Severity of Xerostomia: Evaluation using Xerostomia Questionnaire and Groningen Radiotherapy- Induced Xerostomia Questionnaire
}

\author{
Friendika DAI. Shinta ${ }^{1}$, Nushita Dinar ${ }^{1}$, Hendri Susanto ${ }^{2}$, Dewi Agustina ${ }^{2}$ \\ ${ }^{1}$ Undergraduate Program, Faculty of Dentistry Universitas Gadjah Mada, Yogyakarta, 55281, Indonesia \\ ${ }^{2}$ Department of Oral Medicine, Faculty of Dentistry, Universitas Gadjah Mada, Yogyakarta, 55281, Indonesia \\ Correspondence to: mashendrisusanto@gmail.com
}

\begin{abstract}
One of the oral complications in head and neck radiotherapy is xerostomia. The severity of xerostomia can be observed using objective examination (unstimulated salivary flow rate measurement) and subjective examination (assessment using xerostomia questionnaires). There are two questionnaires used in assessment of xerostomia in head and neck cancer radiotherapy namely Xerostomia Questionnaire (XQ) and Groningen Radiotherapy-Induced Xerostomia Questionnaire (GRIX). Objective: To know the correlation between unstimulated salivary flow rate and severity of xerostomia assessment using two questionnaires. Methods: 30 head and neck cancer patients undergoing radiotherapy at Radiotherapy Department of RSUP Dr. Sardjito Yogyakarta between January-April 2013 were involved in this study. The assessment of xerostomia used xerostomia questionnaires (XQ and GRIX). Unstimulated salivary flow rate was measured in $\mathrm{ml} /$ minutes. Data was analyzed using Spearman Rank Correlation. Results: There is a negative significant correlation between salivary flow rate and severity of xerostomia with correlation coefficient $-0.452(p<0.05)$ and $-0.511(p<0.05)$. Conclusions: There is a correlation between unstimulated salivary flow rate and severity of xerostomia assessment using XQ and GRIX for head and neck cancer patients undergoing radiotherapy at RSUP Dr. Sardjito Yogyakarta.
\end{abstract}

\begin{abstract}
ABSTRAK
Laju alir saliva tanpa stimulasi terkait dengan tingkat keparahan xerostomia: evaluasi dengan Kuesioner Xerostomia dan Groningen Radiotherapy-Induced Xerostomia Questionnaire. Radioterapi kanker kepala dan leher dapat mengakibatkan xerostomia; sel-sel asinar kelenjar saliva rusak sehingga kualitas dan kuantitas saliva menurun. Penilaian keparahan xerostomia menggunakan pemeriksaan obyektif dan subyektif. Pemeriksaan obyektif dilakukan dengan pengukuran sekresi saliva tanpa stimulasi. Pemeriksaan subyektif dilakukan dengan pengisian kuesioner tentang mulut kering diantaranya Xerostomia Questionnaire (XQ) dan Groningen Radiotherapy-Induced Xerostomia Questionnaire (GRIX). Tujuan: Mengetahui hubungan antara sekresi saliva tanpa stimulasi dan penilaian keparahan xerostomia menggunakan dua kuesioner. Metode: Penelitian ini melibatkan 30 pasien kanker kepala dan leher yang menjalani radioterapi di Instalasi Radiologi RSUP Dr. Sardjito Yogyakarta pada bulan Januari-April 2013. Keparahan xerostomia dinilai menggunakan kuesioner xerostomia (XQ dan GRIX). Sekresi saliva tanpa stimulasi diukur selama 15 menit. Data dianalisis menggunakan uji Spearman Rank Correlation. Hasil: Ada hubungan negatif yang signifikan antara sekresi saliva tanpa stimulasi dengan penilaian keparahan xerostomia menggunakan XQ dan GRIX dengan nilai koefisien korelasi $-0,452(p<0,05)$ dan $-0,511$ $(p<0,05)$. Simpulan: Ada hubungan antara sekresi saliva tanpa stimulasi dengan penilaian keparahan xerostomia menggunakan XQ dan GRIX pada pasien radioterapi kepala dan leher di RSUP Dr. Sardjito Yogyakarta. Semakin rendah sekresi saliva tanpa stimulasi maka semakin parah xerostomia yang dirasakan pasien.
\end{abstract}

Keywords: Groningen Radiotherapy-Induced Xerostomia Questionnaire, salivary flow rate, Xerostomia Questionnaire 


\section{INTRODUCTION}

The prevalent of head and neck cancer is $2.8 \%$ of malignancy in the world. ${ }^{1}$ The etiopathogenesis of head and neck cancer are epithelial malignancy of upper gastrointestinal and respiration tracts: paranasal sinuses, nasal cavity, oral cavity, pharynx and larynx. ${ }^{2}$ The head and neck cancer treatments are radiotherapy, combination of radiotheray and surgery, ${ }^{3}$ and chemotherapy. ${ }^{4}$

Head and neck cancer radiotherapy is very effective in certain cases but may give many side effects. One of the side effects is salivary gland damage. ${ }^{5,6}$ This effect results in dry mouth (xerostomia) in head and neck radiotherapy. ${ }^{6-8}$ The Head and Neck radiotherapy dose was up to 70Gy for the primary tumor and give a peripheral dose approximately $50 \mathrm{~Gy}$ for sorrounding area of tumor site. ${ }^{9}$ Radiotherapy dose of 20-40Gy may cause xerostomia ${ }^{10}$ and radiotherapy dose of $26 \mathrm{~Gy}$ for parotid gland may decrease significantly salivary flow rate. ${ }^{11,12}$

Xerostomia may be caused by salivary gland damage, especially parotid gland which is responsible for serous type salivary secretion. The acinar cells may atrophy and degenerated and leads to decrease of serous saliva secretion and change the saliva secretion to a mucinous type. ${ }^{13}$ Mucinous saliva may be one of the sign of xerostomia. ${ }^{5}$ The alteration of saliva secretion may modify the salivary function in the mouth. The alteration of salivary quality and quantity will lead to decrease of saliva ability to protect teeth and oral mucosa, ${ }^{11,12}$ cause alteration in acidity of the mouth $(\mathrm{pH})$, increase mucosal ulceration risk, caries and other oral infections. ${ }^{11}$

Xerostomia may be different in every head and neck radiotherapy patient. The decreased of salivary flow rate or hyposalivation does not always correlate with xerostomia. Patient who complaining xerostomia does not always caused by hyposalivation. ${ }^{14}$ Normally, salivary flow rate is about 1 to $1.5 \mathrm{~L}$ per day $(0.5-1$ $\mathrm{mL} / \mathrm{minutes}$ ). However, the salivary flow rate may be affected by diurnal variation, hydratiton state and nutrition intake and salivary flow rate under $0.1 \mathrm{~mL} / \mathrm{min}$ indicates a hyposecretion or hypofunction of salivary glands. ${ }^{15}$ The salivary gland function can be assessed by subjective examination using xerostomia questionnaire consist of dry mouth questions and/or objective examination using salivary flow rate examination. ${ }^{16,17}$

Xerostomia Questionnaire (XQ) is a type of a valid and reliable questionnaire for assessing xerostomia post head and neck radiotherapy. ${ }^{16,18}$ XQ consists of 8 questions, divided into 2 parts: questions about dry mouth while eating and not eating. ${ }^{16}$ The answer choice of XQ represented as numerical visual analog scale (VAS) ranged 0-10. The higher the score, the more severe dry mouth/uncomfortable sensation of the mouth complained by patients. ${ }^{16}$
Groningen Radiotherapy-Induced Xerostomia Questionnaire (GRIX) is a new valid and reliable questionnaire to assess xerostomia in head and neck radiotherapy consists of 14 questions divided into 4 parts: dry mouth questions during day and night, and sticky saliva during day and night. Answer choices of this questionnaire presented as a likert scale: not at all, a little, quite a bit, and very much. ${ }^{19}$

Xerostomia questionnaire is an important instrument for assessing salivary gland hypofunction in head and neck radiotherapy. The xerostomia assessment may help dentists to provide diagnosis and prognosis for the oral diseases related to xerostomia whether using both xerostomia questionnaire and salivary flow rate examination. Therefore the correlation between salivary flow rate with xerostomia severity assessment using XQ and GRIX needs to be studied, because the assessment of xerostomia will have more clinical relevance to assess salivary gland function impairment than just measuring salivary flow rate.

The objective of this study is to know the correlation between unstimulated salivary flow rate with xerostomia severity assessment using XQ and GRIX for head and neck cancer radiotherapy patients of RSUP Dr. Sardjito Yogyakarta.

\section{METHODS}

This study used cross-sectional method. Head and neck cancer radiotherapy patients of RSUP Dr. Sardjito who involved in this study were adult men or women, have received irradiation at least once ( 2 Gy). The patients did not use pipettes for eating, and agree to become subjects of this study. The XQ and GRIX were translated into Indonesian. The questionnaires in Indonesian translations were translated back into English to know whether the translation was in correct context with the original questionnaires. This study approved by Ethical Committee of Faculty of Medicine Universitas Gadjah Mada.

Subjects were questioned using $\mathrm{XQ}$ and GRIX. In $\mathrm{XQ}$, each question will be scored by 0 if there is no xerostomia and score 1-10 indicate xerostomia with 1 means less xerostomia and 10 mean highest xerostomia feeling (Box 1). Subjects were scored 1 for not at all, 2 for a little, 3 for quite a bit, and 4 for very much in GRIX (Box 2). The total score of XQ and GRIX were obtained by summarizing score from all questions. The higher the xerostomia score, the more severe xerostomia complained by patients.

The unstimulated salivary flow rate was assessed using spitting method. Patients were instructed to collect their saliva for 15 minutes in the tube (Axygen, Mexico). Saliva in the tube was then weighed using analytical 
Box 1. Xerostomia Questionnaire

Rate your difficulty in talking due to dryness

Rate your difficulty in chewing due to dryness

Rate your difficulty in swallowing solid food due to dryness

Rate the frequency of your sleeping problems due to dryness

Rate your mouth or throat dryness when eating food

Rate your mouth or throat dryness while not eating

Rate the frequency of sipping liquids to aid swallowing food

Rate the frequency of sipping liquids for oral comfort when not eating

Answer:

$0=$ no xerostomia, 1 = less xerostomia feeling, $10=$ highest xerostomia feeling

Box 2. Groningen Radiotherapy-Induced Xerostomia Questionnaire

Have you had a dry mouth during the day?

Have you had a dry mouth outdoors?

Have you had difficulties with eating due to a dry mouth?

Have you had a dry mouth during activities?

Have you had difficulties with talking due to a dry mouth?

Did you drink more during the day due to a dry mouth?

Have you had a dry mouth during the night?

Have you had difficulties with sleeping due to a dry mouth?

Did you need to drink during the night due to a dry mouth?

Have you had sticky saliva during the day?

Have you had difficulties with eating due to sticky saliva?

Have you had difficulties with talking due to sticky saliva?

Have you had sticky saliva during the night?

Have you had difficulties with sleeping due to sticky saliva?

Answer:

$1=$ not at all, $2=$ a little, $3=$ quite a bit, and $4=$ very much

scale (gram/min), and the result was converted into $\mathrm{mL} / \mathrm{min}$ with value of 1 gram of saliva $=1 \mathrm{~mL}$ saliva. ${ }^{20}$

Kolmogorov Smirnov test was performed to know the normality of the data distribution. Non parametrical analysis Spearman Rank Correlation was used to analyze the correlation between unstimulated salivary flow rate and xerostomia severity using XQ and GRIX. Confidence interval used in this study was 95\% $(\alpha$ $=0.05$ ) using SPSS 16.0 statistical program (SPSS Incorporation, Chicago, USA).

\section{RESULTS}

Thirty head and neck radiotherapy patients at Radiotherapy Department of RSUP Dr. Sardjito between January to April 2013 were involved in this study. There were 22 men $(73.33 \%)$ and 8 women $(26.67 \%)$ and ranged from $21-76$ years old. Subjects have already received radiotherapy ranging from 2-28 times with radiation dose range of 4-56Gy with mean dose of $22.27 \pm 14.15 \mathrm{~Gy}$. Twenty one subjects were diagnosed with nasopharyngeal carcinoma, while 9 subjects were diagnosed with squamous cell carcinoma located on the tongue ( 3 subjects), mandible
(2 subjects), buccal mucosa (2 subjects) and paranasal sinuses (2 subjects).

Twenty six out of 30 subjects $(86.67 \%)$ in this study complained dry mouth (xerostomia). The mean unstimulated salivary flow rate of the 30 subjects was $0.12 \pm 0.08 \mathrm{~mL} / \mathrm{min}$. According to this result, 16 out of 30 subjects $(53.3 \%)$ were classified to have hyposalivation. The mean score for XQ and GRIX were $30.57 \pm 24.52$ and $30.53 \pm 12.46$.

Kolmogorov Smirnov test result showed that data of unstimulated salivary flow rate and xerostomia score distributed normally $(p>0.05)$. Non parametrical analysis Spearman Rank Correlation was used to analyze the correlation between unstimulated salivary flow rate and xerostomia severity using XQ and GRIX. The non parametrical analysis using Spearman Rank Correlation showed significant negative correlation between unstimulated salivary flow rate with xerostomia severity assessment using XQ and GRIX with correlation coefficient of -0.452 and significance level of 0.012 . This result indicated that the lower the unstimulated salivary flow rate, the more severe xerostomia complained by patient. Correlation test between unstimulated salivary flow rate with xerostomia severity assessment using GRIX also show significant inverse correlation with correlation coefficient of -0.511 with $p<0.005$.

\section{DISCUSSION}

Twenty six subjects (86.67\%) in this study complained xerostomia. Radiotherapy-induced xerostomia may be caused by decrease of saliva amount (hyposalivation) in the mouth due to salivary gland damage. The mechanisms cause the salivary gland damage related to radiotherapy include direct selective damage of cell membrane of cells of the salivary glands that disturb water excretion, late damage to the progenitor and stem cells that inhibit cell renewal, and damage to the cellular environtment of the salivary gland..$^{21,22}$

The unstimulated salivary flow rate will decrease in patients with hyposalivation, while stimulated salivary flow rate remains unchanged. ${ }^{23}$ Saliva was collected at the same time (09.00-12.00) to avoid the effect of cyrcadian rhythm of salivary secretion by salivary glands. Unstimulated salivary flow rate is lower at the morning and reach its peak at evening. ${ }^{24}$

Xerostomia usually appears when salivary flow rate is lower than $0.1-0.2 \mathrm{~mL} / \mathrm{min} .{ }^{24}$ Xerostomia will not appear when the salivary flow rate is $0.1-0.3 \mathrm{~mL} /$ min. ${ }^{25}$ The unstimulated salivary flow rate is less than $0.1 \mathrm{~mL} / \mathrm{min}$ in hyposalivation. The mean unstimulated salivary flow rate found in this study was $0.12 \mathrm{~mL} / \mathrm{min}$, indicating that hyposalivation was not found in the most subjects of this study. 
There were sixteen subjects $(53.33 \%)$ with hyposalivation. Ten of them $(33.33 \%)$ complained xerostomia. Xerostomia complained by those patients probably caused by qualitative change of saliva. Radiotherapy-induced xerostomia may occur as a result of qualitative change of saliva without quantitative change. Qualitative change of saliva in the post head and neck cancer radiotherapy is the increase of the saliva viscosity and acidity $(\mathrm{pH}) .^{15}$

Psychological factors may also affect xerostomia severity complained by patients. Change in the autonomic innervation of salivary glands as a result of simpathetic stimulation by anxiety, stress, depression, and insomnia may cause change in salivary composition. ${ }^{26}$ Saliva consists of two components secreted by different mechanisms. Fluid component, include ions, produced by parasimpathetic stimulation. Protein components produced by simpathetic stimulation. Parasimpathetic stimulation induce salivary glands to produce saliva with high fluid contents. Simpathetic stimulation induce salivary glands to produce saliva with high concentration of protein. This high protein concentration in saliva make saliva becomes thick and leads dry mouth sensation. ${ }^{27}$

There were four subjects (13.33\%) who didn't complaint xerostomia and did not show hyposalivation. It may be caused by radiation doses received by those patients were lower than 26 Gy. The hyposalivation may be reversible because there is no salivary gland damage after radiotherapy. The salivary flow rate observed will significantly decrease after the dose received by parotid gland increases more than 26 Gy. Salivary glands will repair gradually if the dose received is not more than $25 \mathrm{~Gy}{ }^{11,18}$

The achievement of this study is that the correlation between unstimulated salivary flow rate with severity xerostomia assessment using GRIX was stronger than XQ. It probably caused by difference in questions of the two questionnaires affects their sensitivity in assessing xerostomia.

Xerostomia Questionnaire consists of 8 questions divided into 2 parts: questions related to dry mouth while eating and not eating. The XQ only distinguish xerostomia complaints related to stimulated and unstimulated salivary flow rate, ${ }^{16,18}$ while GRIX divided into 4 parts: questions related to dry mouth during day and night and sticky saliva during day and night. The more detailed questions probably makes GRIX more sensitive to detect xerostomia in the patients because GRIX can assess xerostomia objectively by detect if there is sticky saliva. ${ }^{19}$

One of the factors that affects questionnaire sensitivity for assessing problems is the ability of questionnaires to detect xerostomia feeling at different time points. ${ }^{28}$
Some patients complained dry mouth during day and night, some patients complained dry mouth only during day, and the rest complained dry mouth only during night. Questions of GRIX separate clearly and specifically questions about dry mouth during day, night, or both. ${ }^{19}$

The alternative answers of XQ and GRIX also contributes to the result of this study. Most of the patients had different perception when they asked to give score ranging from 0 to 10 in XQ. The difference of scores 3 and 4, 4 and 5, 5 and 6, etc is difficult to be determined by the patients and the score may be different with the patient's perception. The answers of GRIX is a likert scale. Most of the subjects did not find any difficulty to answer the GRIX questionnaire and the GRIX score may be more represents patients's dry mouth severity.

Questionnaire with likert scale is easier to use so the respondent more prefer this type of questionnaire. ${ }^{29}$ Questionnaire with numerical scale is more sensitive to assess patients condition, however, patients were confused to fill the questionnaire and they need more time to complete the questionnaire. ${ }^{30}$

The shortcoming of this study is there were small number of subject involved. Therefore the result of this study can't be generalized yet for larger population. Other factors may affect unstimulated salivary flow rate like chemotherapy, other xerogenic drug consumptions and angle of radiation to the salivary glands. Those factors did not count into analysis in this study. Questionnaire's consistency or reliability is not known in this study. The reliability test could not be performed because subjects did not have adequate medical condition to participate in longer examination. Most of the subjects also felt difficult to collect their saliva in a smal saliva for 15 minutes, because the saliva characteristics of the patients were thick and sticky so too little saliva volume was collected. It might be helpful if the saliva tube used have greater diametres to avoid patients difficulty in collecting their saliva into the tube.

Further study involved more patients need to be held so the result of the study becomes more representative. Subjects selection should be perfomed so the subjects of the study consist of patients who have adequate medical condition and reliability test of the questionnaires can be performed. The effect of chemotherapy, drugs consumption, radiation angle, dosage and age of the patients to xerostomia severity should be analyzed.

\section{CONCLUSION}

Unstimulated salivary flow rate correlates with the severity of xerostomia assessment using XQ and 
GRIX for head and neck cancer patients undergoing radiotherapy at RSUP Dr. Sardjito Yogyakarta. The lower the unstimulated salivary flow rate, the more severe xerostomia complained.

\section{ACKNOWLEDGEMENT}

The authors thank to Radiotherapy Department of RSUP Dr. Sardjito, Yogyakarta, Indonesia, head and neck cancer radiotherapy patients of RSUP Dr. Sardjito Yogyakarta, and Research Laboratory of Faculty of Dentistry Universitas Gadjah Mada, Yogyakarta, Indonesia.

\section{REFERENCES}

1. Jemal A, Siegel R, Ward E. Cancer statistics. CA Cancer J Clin. 2006;56:106-30.

2. Cognetti DM, Weber RS, Lai SY. Head and neck cancer: an evolving treatment paradigm. Cancer. 2008;113:1911-32.

3. Scully C. Oral and maxillofacial medicine. Elsevier :Edinburgh. 2004.

4. Sciubba JJ, Goldenberg D. Oral complications of radiotherapy. Lancet Oncol. 2006;7:175-83.

5. Marmiroli L, Salvi G, Caiazza A, Di Rienzo L, Massaccesi, Murino P. Dose and volume impact on radiation induced xerostomia. Rays. 2005;30:145-8.

6. Fang FM, Tsai WL, Chen HC, Hsu HC, Hsiung $\mathrm{CY}$, Chien CY, et al. Intensity-modulated or conformal radiotherapy improves the quality of life of patients with nasopharyngeal carcinoma: comparisons of four radiotherapy techniques. Cancer. 2007;109:313-21.

7. Langendijk J, Slotman B, van der Waal I. Riskgroup definition by recursive partitioning analysis of patients with squamous cell head and neck carcinoma treated with surgery and postoperative radiotherapy. Cancer. 2005;104:1408-17.

8. Taheri-Kadkhoda Z, Björk-Eriksson, Nill S, Wilkens JJ, Oelfke U, Johanson K, et al. Intensitymodulated radiotherapy of nasopharyngeal carcinoma: a comparative treatment planning study of photons and protons. Radiat Oncol. 2008;3:1-15.

9. Chan ATC, Felip E. Nasopharyngeal cancer: ESMO Clinical recommendations for diagnosis, treatment and follow-up. Ann Oncol. 2009;20:1235.

10. Gregoire V, De Neve W, Eisbruch A, Lee N, van den Weyngaert $\mathrm{D}$, van Gestel D. Intensitymodulated radiation therapy for head and neck carcinoma. Oncologist. 2007;12: 555-64.

11. Eisbruch A, Ship JA, Dawson LA, Kim HM, Bradford CR, Terrell JE. Salivary gland sparing and improved target irradiation by conformal and intensity modulated irradiation of head and neck cancer. World J Surg. 2003;27:832-7.

12. Chambers MS, Garden AS, Kies MS, Martin JW. Radiation induced xerostomia in patients with head and neck cancer: pathogenesis, impact on quality of life and management. Head Neck. 2004;26: 796-807.

13. Nomayr A, Lell M, Sweeney R, Baultz W, Lukas P. MRI Appearance of radiation-induced changes of normal cervical tissues. Eur Radiol. 2001;180717.

14. Thomson WM, Chalmers JM, Spencer AJ, Williams SM. The Xerostomia inventory: a multi-item approach to measuring dry mouth. Community Dent Health. 1999;16:12-7.

15. Mravak-Stipetić M. Xerostomia - diagnosis and treatment. Rad 514 Med Sci. 2012;38: 69-91.

16. Meirovitz A, Murdoch-Kinch CA, Schipper M, Pan C, Eisbruch A. Grading xerostomia by physicians or by patients after intensitymodulated radiotherapy of head and neck cancer. Int J Radiat Oncol Biol Phys. 2006;66:445-53.

17. Regezi JA, Sciubba JJ. Oral Pathology clinicalpathologics correlations. 5th ed. St. Louis: WB Saunders Co; 2008.

18. Eisbruch A, Kim HM, Terrell JE. Xerostomia and its predictors following parotid-sparing irradiation of head and neck cancer. Int J Radiat Oncol Biol Phys. 2001;50:695-704.

19. Beetz I, Burlage FR, Bijl HP, Chouvalova $\mathrm{OH}$, Miranda EMC, Christianen, et al. The Groningen radiotherapy-induced xerostomia questionnaire: development and validation of a new questionnaire. Radiother Oncol. 2010;97: 127-31.

20. Osailan S, Pramanik R, Shirodaria S, Challacombe SJ, Proctor GB. Investigating the relationship between hyposalivation and mucosal wetness. Oral Dis. 2010;17:1-26.

21. Berk LB, Shivnani AT, Small W. Pathophysiology and management of radiation-induced xerostomia. J Support Oncol. 2005;3:191-200.

22. Fox PC. Xerostomia: recognition and management. Dent Assist. 2008;77:18-44.

23. Wang SL, Zhao ZT, Li J, Zhu XZ, Dong H, Zhang YG. Investigation of the clinical value of total saliva flow rates. Arch Oral Biol. 1998;43:39-43.

24. Rantonen P. Viscosity of whole saliva. Acta Odontol Scand. 1998;56:210-4.

25. Dawes C. How much saliva is enough for avoidance of xerostomia?. Caries Res. 2004;38:236-40.

26. Scully C, Felix DH. Oral medicine - Update for the dental practitioner. Dry mouth and disorders of salivation. Br Dent J. 2005;199:423-7.

27. Porter SR, Scully C, Hegarty AM. An update of the etiology and management of xerostomia. Oral Surg Oral Med Oral Pathol Oral Radiol Endod. 2004;97:28-46. 
28. Ikebe K, Nokubi T, Sajima H, Kobayashi S, Hata $\mathrm{K}$, Ono $\mathrm{T}$, et al. Perception of dry mouth in a sample of community-dwelling older adults in Japan. Spec Care Dentist. 2001;21:52-9.

29. van Laerhoven H, van der Zaag-Loonen HJ, Derkx BHF. A comparison of likert scale and visual analogue scales as response options in children's questionnaires. Acta Paediatr. 2004;93: 830-5.

30. Williamson A, Hoggart B. Pain: a review of three commonly used pain rating scales. J Clin Nurs. 2004;14: 798-804. 